Research Article

\title{
Evaluation of implementation of "5S Campaign" in urban health center run by municipal corporation, Gujarat, India
}

\author{
Vijay P. Pandya ${ }^{1 *}$, Umed V. Patel ${ }^{2}$, Bhavesh R. Kanabar ${ }^{2}$, Isha V. Joshi' ${ }^{1}$, Amiruddin M. Kadri
}

${ }^{1}$ Health Department, Municipal Corporation, Rajkot, Gujarat, India

${ }^{2}$ Community Medicine Department, P. D. U. Govt. Medical College, Rajkot, Gujarat, India

Received: 21 May 2015

Revised: 26 May 2015

Accepted: 07 June 2015

\author{
*Correspondence: \\ Dr. Vijay P. Pandya, \\ E-mail: drpandya2902@gmail.com
}

Copyright: (C) the author(s), publisher and licensee Medip Academy. This is an open-access article distributed under the terms of the Creative Commons Attribution Non-Commercial License, which permits unrestricted non-commercial use, distribution, and reproduction in any medium, provided the original work is properly cited.

\begin{abstract}
Background: Despite significant progress in improvement of Government health care delivery system over past decade, community is reluctant to accept it because of substandard level of quality. " $5 \mathrm{~S}$ " is one of the strategies used to improve the physical quality and work efficiency of organization. 5S stands for five Japanese words which can be translated in English as Sort, Set in order, Shine, Standardize, and Sustain. Rajkot Municipal Corporation has adopted $5 \mathrm{~S}$ strategy within its health centers with the aim to improve image of public health care facility among community and thereby to increase coverage of health services. This study was conducted to assess $5 \mathrm{~S}$ implementation status at all Urban Heath Centers under health department of Rajkot Municipal Corporation, Gujarat, India.

Methods: "5S" was implemented by the corporation in campaign mode in 18 Urban Health Centers in July 2014. Campaign included training, baseline assessment, and observing 5S week. A cross sectional study was carried out by personal observation and interview to assess the implementation of $5 \mathrm{~S}$ campaign. Standard audit check list recommended by the State Quality Assurance Cell, Gujarat was used to evaluate.

Results: Overall; all five components of 5S showed significant improvement $(\mathrm{p}<0.001)$ with highest improvement in Sorting and Setting in order. Significant improvement in utilization of Out Patient, laboratory services, immunization, family planning services etc were observed in comparison to previous year's corresponding period.

Conclusions: Significant improvement in utilization in major health care services was noted in the study after implementation of $5 \mathrm{~S}$. ' $5 \mathrm{~S}$ ' practice can be sustained with sincere and continuous efforts.
\end{abstract}

Keywords: Quality, Public healthcare services, Urban health centers, 5S

\section{INTRODUCTION}

India has made significant progress in improvement of health care delivery system over past decade. The Government of India's various initiatives in terms of missions, schemes and programmes have largely contributed to this. In present modern era, the continual improvement of service quality in health care sector is of prime consideration to ensure patients' satisfaction. The health care sector is a fastest and largest growing sector in India. ${ }^{1}$ In recent past Government of India is also giving much emphasis on improvement of quality of Government healthcare services. Many times patients choose private health care sector because of substandard level quality of Government health care services. ${ }^{2}$ Government of India has initiated various initiatives to improve physical quality of health care system by introducing various accreditations and standards e.g. National Accreditation Board for Hospitals and Healthcare providers $(\mathrm{NABH})^{3}$, Indian Public Health Standards, 5S etc. Three types of qualities can be addressed in reference to Government health care facility: 1). Medical care: includes availability of well functioning diagnostic and treatment facility, 2). Physical appearance: includes availability of good quality infrastructure, 3). 
Human behavior: includes interpersonal behavior of staff with patients and relatives.

The Concept of 5S evolved from a manufacturing enterprise in Japan and was later on applied to business sector in western countries in 1980. 5S stands for five Japanese words Seiri, Seiton, Seisou, Seiketsu, and Shitsuke which can be translated in English as Sort, Set in order, Shine, Standardize, and Sustain. All these words represent following set of practices; 1 . Sort: To sort and systematically discard items those are not needed in the workplace 2. Set in Order: To arrange necessary items in a neat and systematic manner so that they can be easily retrieved for use and to returned after use. 3. Shine: To clean and inspect the workplace thoroughly so that there is no dirt on the floor, machines and equipments etc. 4. Standardize: To maintain a high standard of workplace organisation by keeping everything clean and orderly at all times. 5. Sustain: To train people to practice the $5 \mathrm{~S}$ system continuously so that it becomes habitual and ingrained in the culture of the organisation.

Lacks of cleanliness and long waiting time are amongst the prime reasons to avoid Government healthcare facility. $5 \mathrm{~S}$ is a lean method of workplace organization. Implementation of $5 \mathrm{~S}$ in health care sector can ensure cleaner and organised workplace and so that patient friendly environment is created. Along with improving the physical quality of the work place; it also increases the work efficiency. $5 \mathrm{~S}$ encourages streamlined inventories, clutter free workspaces, and processes to maintain housekeeping standards. This strategy is being used in healthcare to reduce inventory, create space, and reduce travel and search times. Each stage of a $5 \mathrm{~S}$ project has an impact on safety, from sort where broken or expired items are removed, to sustain where ongoing cleaning, maintenance, and quality checks are routinely conducted. ${ }^{5}$ It also reduces lead time and change over time by streamlining the operations. Ultimately patients' complains are reduced and coverage of health services of Government health care facilities are increased. Government of Gujarat had issued a circular regarding implementation of $5 \mathrm{~S}$ in all Government health care facilities. Health department of Rajkot Municipal Corporation implemented $5 \mathrm{~S}$ practice in campaign mode in all 18 Urban Health Centres (UHC) of the city from July 2014.

It is necessary to know what the implementation status is and changes happened at the centre after implementation of the $5 \mathrm{~S}$ in the public health centre. The current study was planned with the same aim, with objectives to know implementation status of all components of " $5 \mathrm{~S}$ " in all Urban Health Centres, to know the change in different $5 \mathrm{~S}$ components after campaign and to know effects of $5 \mathrm{~S}$ on service utilization.

\section{METHODS}

Municipal Corporation has implemented 5S approach in mission mode in all the 18 UHCs of the Rajkot City in month of July 2014. Under the title "5S Campaign", the $5 \mathrm{~s}$ practice, was modulated and implemented in healthcare institutions in mission mode. As a part of campaign; baseline assessment, modules and IEC material preparation and training of all staffs with celebration of a week for $5 \mathrm{~S}$ implementation were carried out.

Day to day planning was done and intensive efforts were carried out for sorting, setting in order, shining and standardizing at all the centres during this campaign. Actual process of $5 \mathrm{~S}$ implementation consisted of proper arrangement of all instruments, equipments, furniture, materials, record-registers, IEC materials etc. along with disposal of old and unused materials. It also included accurate labelling at all important places and good housekeeping and cleanliness all over the workplaces. Strengthening of Bio Medical Waste Management and proper maintenance of laboratory and pharmacy were also ensured.

\section{S Audit tool}

A cross sectional, observational type study was carried out to assess the 18 UHCs by use of a structured audit checklist recommended by State Quality Assurance Cell, Gujarat, India. Same audit checklist was used for both baseline assessment and external evaluation. Audit check list had questionnaire for all components of $5 \mathrm{~S}$ viz. Five questions for Sort; Four questions for Set in order; Twenty Four questions for Shine; Seven questions for Standardize and Five questions for Sustain. Total questions were 45. Each sub component (question) was assessed with personal observation and scored from 1 to 5. The scoring is in descending order viz. 5 for excellent, 4 for good, 3 for average, 2 for poor and 1 for very poor performance.

Indicators regarding performance of various health care delivery services were pre-decided i.e. Out Patient Department, laboratory tests, Family planning service, beneficiaries of schemes, etc. for measuring the impact of the '5 S Campaign'. Baseline internal assessment was carried out by Medical officers of all UHCs using the preformed $5 \mathrm{~S}$ audit checklist and score was noted in the month of July 2014. Actions were taken for ensuring necessary improvement in $5 \mathrm{~S}$ implementation as per feedback of baseline assessment.

External evaluation was carried out by Community Medicine Department, P. D. U. Govt Medical College, Rajkot, during November 2014, i.e. after about 3 months of $5 \mathrm{~S}$ implementation using same audit check list.

During visit of UHCs, whole campus, OPD room, indoor room, laboratory, pharmacy, operation theatre (if 
available), place for biomedical waste storage, store, overhead water tank, underground water tank etc. were directly observed. Cleanliness status, separation of useful and non useful items, presence of non useful items in working area, display of signage board, labelling, arrangement of files, instruments etc. in cupboards; medicines in pharmacy, autoclaving, checklist and monitoring sheet of cleanliness were assessed while inspecting all areas in health centres.

\section{RESULTS}

During our visits to health centres, it was noticed that almost at all the centres sorting of unnecessary items was done and required items were arranged in a visually organised manner so that they could be easily retrieved at the time of use and returned back after use. Cleanliness status of all the Urban Health centres was satisfactory. Almost at all places most of the files, cupboards, furniture, etc. were labelled. Signage board were displayed at all the rooms. However maintenance of bio medical waste system and autoclave register had further scope of improvement. Cleanliness and its monitoring responsibilities were allotted at almost all the UHC but it was required to be documented. Enough logistics were available at all the UHC for cleanliness. Cleanliness monitoring sheet needed to be displayed at various areas like toilet, chambers, etc. with daily check it by supervisor.

Maximum score for each component was 5. Only one component was below 3 score before start of the campaign but on evaluation all components scored more than 3. Table 1 shows significant increase $(\mathrm{p}<0.001)$ in score of all components of $5 \mathrm{~S}$ after its implementation. On evaluation 'Sorting' scored highest (3.80) followed by Set in order (3.79) and Standardize (3.71). Points in improvement were ranging from 0.19 to 0.89 with lowest improvement in 'shine' and highest in the component 'Sustain' (Table 1).

\section{Table 1: Comparison of average score of various ' $S$ ' of all Urban Health Centers before and after " $5 \mathrm{~s}$ Campaign".}

\begin{tabular}{|c|c|c|c|c|}
\hline \multirow[b]{2}{*}{$\begin{array}{l}5 \mathrm{~S} \\
\text { component }\end{array}$} & \multicolumn{2}{|c|}{ Average Score } & \multirow{2}{*}{$\begin{array}{l}\text { Average } \\
\text { score } \\
\text { increased } \\
\text { in three } \\
\text { months }\end{array}$} & \multirow[b]{2}{*}{$\begin{array}{l}\mathbf{P} \\
\text { value }\end{array}$} \\
\hline & $\begin{array}{r}\text { July } \\
2014\end{array}$ & $\begin{array}{l}\text { November } \\
2014\end{array}$ & & \\
\hline S1 -Sort & 3.21 & 3.80 & 0.59 & $<0.001$ \\
\hline $\begin{array}{l}\text { S2-Set in } \\
\text { Order }\end{array}$ & 3.06 & 3.79 & 0.73 & $<0.001$ \\
\hline S3-Shine & 3.41 & 3.60 & 0.19 & $<0.001$ \\
\hline $\begin{array}{l}\text { S4- } \\
\text { Standardize }\end{array}$ & 3.08 & 3.71 & 0.63 & $<0.001$ \\
\hline S5-Sustain & 2.75 & 3.64 & 0.89 & $<0.001$ \\
\hline
\end{tabular}

It is evident from the Table 2 and Table 3 that there is significant improvement in each component of $5 \mathrm{~S}$ in all the Urban Health Centres ( $p<0.001)$. While all the centres scored below three 'average score' before the campaign, but after campaign 4 centres crossed the score of 4 and reached towards excellent. Except one centre all other centres scored more than 3 scores. Nana Mauva UHC scored highest score (4.61) as was leading in all the components of $5 \mathrm{~S}$ after its implementation with above "Good" level of score in all the component and even excellent score in 'Setting In Order'. Ambedakar nagar UHC and Bhagvatipara UHC followed the Nana Mauva UCH with score of 4.38. One UHC (IMA) remained below 3 even after the campaign with marginal improvement of 0.23 points (Table 2 and 3, Figure 1 ).

Table 4 shows improvement in selected indicators of health care delivery services by Urban Heath centres after implementation of $5 \mathrm{~S}$.

\section{DISCUSSION}

Despite its origin in manufacturing, 5S projects have been documented in a variety of settings in healthcare through a project administered by the National Health Service (UK) including wards of acute patient facilities, finance, information technology, laboratories, and community offices. ${ }^{6}$ This initiative presents a systematic way of making improvements in various hospital settings, including wards, operation theatres and community services, mainly through the application of the $5 \mathrm{~S}$ approach. In present study the result of $5 \mathrm{~S}$ campaign was evident with improvement in the average score for each "S" and statistically significant improvement in the all 18 UHC. The fifth "S-Sustain" is the most challenging part of a 5S initiative. Maintaining the first four Ss, once the excitement of the initial $5 \mathrm{~S}$ event has concluded requires conscious effort on the part of all employees, not just the ones directly involved in the initial event. ${ }^{7}$ The highest improvement in "Sustain" can be considered a good achievement as it indicates that $5 \mathrm{~S}$ campaign has moved to the right direction of institutionalization.

Our study showed increase in utilization of major health care services after implementation of $5 \mathrm{~S}$ at Urban Health Centres of Rajkot City in the absence of any other major change in the health care delivery system. The increase in utilization indirectly indicates that client have started rating the health care service higher than past. In another qualitative study of staff perception about implementation of $5 \mathrm{~S}$ management method for lean healthcare at a health centre in Senegal showed that participants perceived changes in their own and others' attitude and behaviour after the $5 \mathrm{~S}$ program implementation. Participant also noticed change in the quality of health services particularly in patient centeredness and safety domain. Almost all the participants mentioned that the $5 \mathrm{~S}$ program facilitated the identification of items, and hence reduced time spent searching for an item. ${ }^{4}$ 
Table 2: Comparison of average score of different $\mathbf{S}$ components in different Urban Health Centers before and after "5s Campaign" (n=18).

\begin{tabular}{|l|c|c|c|c|c|c|c|c|c|c|}
\multirow{2}{*}{ Name of UHC } & \multicolumn{2}{|c|}{ S1 -Sort } & \multicolumn{2}{c|}{$\begin{array}{c}\text { S2-Set in } \\
\text { Order }\end{array}$} & \multicolumn{2}{c|}{ S3-Shine } & \multicolumn{2}{c|}{$\begin{array}{c}\text { S4- } \\
\text { Standardize }\end{array}$} & \multicolumn{2}{c|}{ S5-Sustain } \\
\cline { 2 - 13 } & $\begin{array}{l}\text { July } \\
\mathbf{2 0 1 4}\end{array}$ & $\begin{array}{l}\text { Nov. } \\
\mathbf{2 0 1 4}\end{array}$ & $\begin{array}{c}\text { July } \\
\mathbf{2 0 1 4}\end{array}$ & $\begin{array}{c}\text { Nov. } \\
\mathbf{2 0 1 4}\end{array}$ & $\begin{array}{c}\text { July } \\
\mathbf{2 0 1 4}\end{array}$ & $\begin{array}{c}\text { Nov. } \\
\mathbf{2 0 1 4}\end{array}$ & $\begin{array}{c}\text { July } \\
\mathbf{2 0 1 4}\end{array}$ & $\begin{array}{c}\text { Nov. } \\
\mathbf{2 0 1 4}\end{array}$ & $\begin{array}{c}\text { July } \\
\mathbf{2 0 1 4}\end{array}$ & $\begin{array}{c}\text { Nov. } \\
\mathbf{2 0 1 4}\end{array}$ \\
\hline Nana Mauva & 3.40 & 4.80 & 3.75 & 5.00 & 3.57 & 4.09 & 4.00 & 4.57 & 4.00 & 4.60 \\
\hline Ambedakar Nagar & 3.80 & 4.20 & 3.25 & 4.25 & 3.87 & 4.21 & 3.71 & 4.85 & 3.80 & 4.40 \\
\hline Bhagvatipara & 3.67 & 4.33 & 3.00 & 4.50 & 3.85 & 4.20 & 3.71 & 4.28 & 4.00 & 4.60 \\
\hline Ranchod Nagar & 3.40 & 4.40 & 3.50 & 4.00 & 3.50 & 3.77 & 3.57 & 4.85 & 2.80 & 3.40 \\
\hline Pranami Chowk & 4.00 & 4.40 & 3.75 & 4.75 & 3.50 & 3.63 & 2.57 & 3.57 & 2.00 & 3.40 \\
\hline Sadar & 2.40 & 2.80 & 3.50 & 4.25 & 4.05 & 4.10 & 3.29 & 3.71 & 3.50 & 4.75 \\
\hline AKhil Hind Mahila & 3.60 & 4.00 & 3.50 & 4.25 & 3.61 & 3.73 & 3.57 & 4.00 & 3.00 & 3.60 \\
Parishad (AHMP) & & & & & & & & & & \\
\hline Rampark & 3.80 & 4.20 & 3.50 & 4.25 & 3.62 & 3.61 & 3.00 & 3.66 & 2.80 & 3.80 \\
\hline Junction Plot & 2.60 & 3.00 & 3.25 & 3.25 & 4.00 & 4.04 & 3.71 & 4.14 & 2.80 & 4.50 \\
\hline Morbi Road & 3.00 & 3.60 & 2.75 & 3.75 & 3.69 & 3.75 & 2.57 & 3.71 & 1.80 & 3.60 \\
\hline Mavdi & 2.80 & 4.20 & 2.50 & 4.00 & 2.54 & 3.31 & 2.29 & 3.14 & 2.20 & 3.40 \\
\hline Vijay Plot & 3.20 & 3.80 & 2.50 & 3.00 & 3.57 & 3.61 & 3.57 & 4.28 & 2.60 & 3.20 \\
\hline Ramnathpara & 4.00 & 4.40 & 3.00 & 3.75 & 3.42 & 3.45 & 2.14 & 2.71 & 2.40 & 3.20 \\
\hline Nandavvan & 3.60 & 4.20 & 2.50 & 3.00 & 3.52 & 3.57 & 2.71 & 3.14 & 2.80 & 3.40 \\
\hline Hudko & 2.80 & 3.20 & 3.25 & 3.25 & 3.14 & 3.14 & 3.29 & 3.57 & 2.80 & 3.20 \\
\hline Champak Vora & 2.60 & 2.80 & 2.75 & 3.50 & 2.65 & 2.70 & 3.17 & 3.66 & 2.40 & 3.20 \\
\hline Narayan Nagar & 3.20 & 3.60 & 3.00 & 3.75 & 3.23 & 3.59 & 1.86 & 2.28 & 1.60 & 2.40 \\
\hline Indian MedicaI & 2.00 & 2.40 & 1.75 & 1.75 & 2.10 & 2.28 & 2.71 & 2.71 & 2.20 & 2.80 \\
Association (IMA) & & & & & & & & & \\
\hline
\end{tabular}

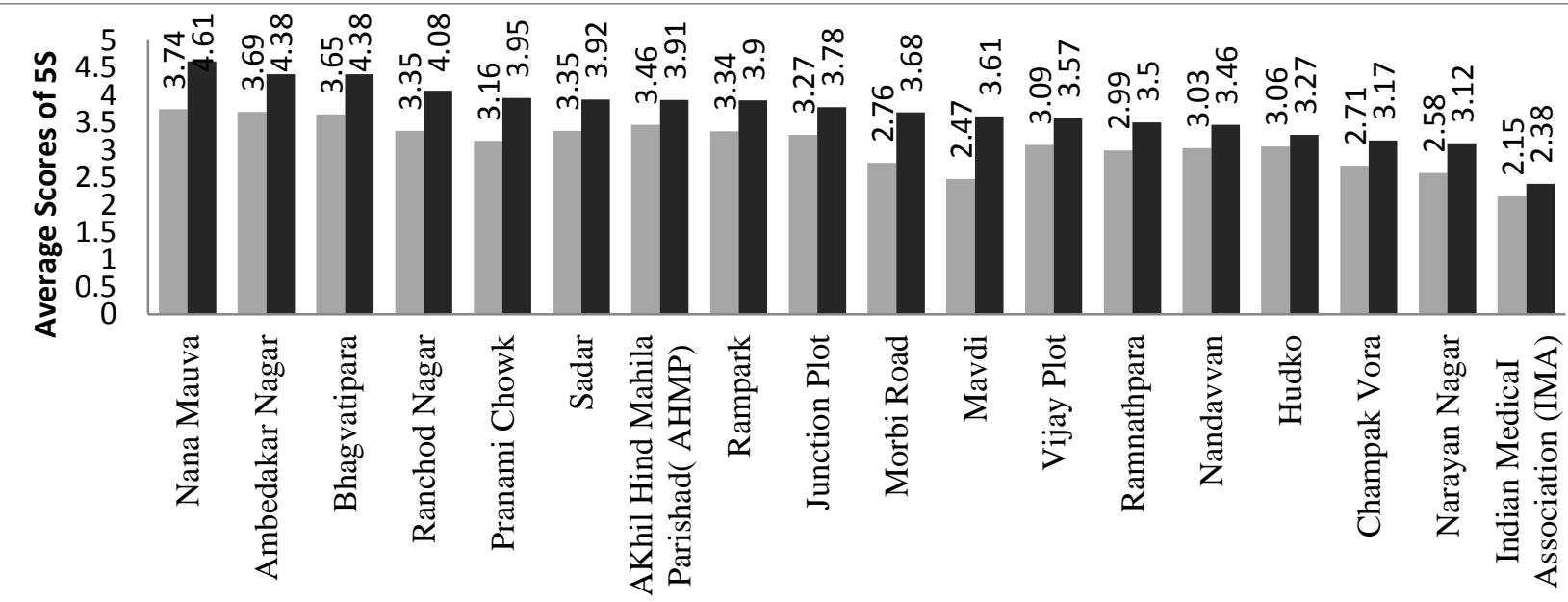

Name of UHCs

- Total Average Score Before Campaign

Total Average Score After Campaign

Figure 1: Comparison of Total average score of $5 \mathrm{~S}$ in different Urban Health Centres before and after " $5 \mathrm{~s}$ Campaign".

In another study at the Bellevue Surgery Centre; after 5S implementation more than $90 \%$ of patients and families gave a 9 or 10 rating for overall care. ${ }^{8}$ ThedaCare, a Wisconsin-based integrated health system, reduced inpatient total cost of care by $25 \%$ while improving patient satisfaction to nearly $100 \%$ of patients; rating their care 5 out of 5 following $5 \mathrm{~S}$ implementation.,
Findings of above mentioned studies are in line with our findings.

\section{Limitation of the study}

Scope of subjectivity in scoring can be there. Baseline and last assessment were carried out by different 
investigators of different institutes. The utilization data is based on the records from UHC.

Table 3: Comparison of total average score of $5 \mathrm{~S}$ in different Urban Health Centers before and after " $5 \mathrm{~s}$ Campaign" $(n=18)$.

\begin{tabular}{|c|c|c|c|}
\hline \multirow[b]{2}{*}{ Name of UHC } & \multicolumn{2}{|c|}{ Average Score } & \multirow{2}{*}{$\begin{array}{l}\text { Point } \\
\text { increase }\end{array}$} \\
\hline & $\begin{array}{r}\text { July } \\
2014\end{array}$ & $\begin{array}{l}\text { November } \\
2014\end{array}$ & \\
\hline Nana Mauva & 3.74 & 4.61 & 0.87 \\
\hline $\begin{array}{l}\text { Ambedakar } \\
\text { Nagar }\end{array}$ & 3.69 & 4.38 & 0.69 \\
\hline Bhagvatipara & 3.65 & 4.38 & 0.73 \\
\hline Ranchod Nagar & 3.35 & 4.08 & 0.73 \\
\hline $\begin{array}{l}\text { Pranami } \\
\text { Chowk }\end{array}$ & 3.16 & 3.95 & 0.79 \\
\hline Sadar & 3.35 & 3.92 & 0.57 \\
\hline $\begin{array}{l}\text { AKhil Hind } \\
\text { Mahila } \\
\text { Parishad( } \\
\text { AHMP) }\end{array}$ & 3.46 & 3.91 & 0.45 \\
\hline Rampark & 3.34 & 3.90 & 0.56 \\
\hline Junction Plot & 3.27 & 3.78 & 0.51 \\
\hline Morbi Road & 2.76 & 3.68 & 0.92 \\
\hline Mavdi & 2.47 & 3.61 & 1.14 \\
\hline Vijay Plot & 3.09 & 3.57 & 0.48 \\
\hline Ramnathpara & 2.99 & 3.50 & 0.51 \\
\hline Nandavvan & 3.03 & 3.46 & 0.43 \\
\hline Hudko & 3.06 & 3.27 & 0.21 \\
\hline Champak Vora & 2.71 & 3.17 & 0.46 \\
\hline Narayan Nagar & 2.58 & 3.12 & 0.54 \\
\hline $\begin{array}{l}\text { Indian MedicaI } \\
\text { Association } \\
\text { (IMA) }\end{array}$ & 2.15 & 2.38 & 0.23 \\
\hline асие & . & 3.724 & \\
\hline
\end{tabular}

\section{CONCLUSION}

Significant improvement in utilization in major health care services was noted in the study after implementation of 5S. Almost all the Urban Health Centres showed improvement in score of all components of $5 \mathrm{~S}$ as compared to baseline score and this ' $5 \mathrm{~S}$ ' practice can be sustained with sincere and continuous efforts.

\section{Recommendation}

It is recommended that all Health care delivery system should adopt $5 \mathrm{~S}$ strategies to improve the quality and coverage of health services.

\section{ACKNOWLEDGEMENTS}

Authors would like to acknowledge all staff members of UHC for their cooperation and support. Also authors would like to extend their special thanks to all the staff members of the health division of Municipal Corporation as well as the members of Community Medicine Department who were involved in the $5 \mathrm{~S}$ study and contributed towards its successful execution.

\section{Funding: No funding sources \\ Conflict of interest: None declared \\ Ethical approval: Not required}

Table 4: Impact of 5S implementation on health care delivery service provided by Urban Health Centres.

\begin{tabular}{|c|c|c|c|}
\hline Indicators & $\begin{array}{c}\text { 2013-14 } \\
\text { (Aug. to } \\
\text { Feb.) }\end{array}$ & $\begin{array}{c}2014-15 \\
\text { (Aug. to } \\
\text { Feb.) }\end{array}$ & $\begin{array}{c}\text { Percentage } \\
\text { increase }\end{array}$ \\
\hline $\begin{array}{l}\text { Number of } \\
\text { patients } \\
\text { consulted in } \\
\text { Out Patient } \\
\text { Department }\end{array}$ & 106112 & 249173 & $134.8 \%$ \\
\hline $\begin{array}{l}\text { Number of } \\
\text { Laboratory } \\
\text { Tests } \\
\text { performed }\end{array}$ & 48953 & 76230 & $55.7 \%$ \\
\hline $\begin{array}{l}\text { Number of } \\
\text { IUCD inserted }\end{array}$ & 5429 & 6218 & $14.5 \%$ \\
\hline $\begin{array}{l}\text { Number of } \\
\text { Sterilisation } \\
\text { operations } \\
\text { performed }\end{array}$ & 1001 & 1352 & $35.1 \%$ \\
\hline $\begin{array}{l}\text { Number of } \\
\text { beneficiaries of } \\
\text { Janni Suraksha } \\
\text { Yojana }\end{array}$ & 723 & 1544 & $113.6 \%$ \\
\hline $\begin{array}{l}\text { Number of } \\
\text { beneficiaries of } \\
\text { Kasturba } \\
\text { Poshan Sahay } \\
\text { Yojana }\end{array}$ & 2334 & 3185 & $36.5 \%$ \\
\hline $\begin{array}{l}\text { Number of } \\
\text { beneficiaries of } \\
\text { Chiranjeevi } \\
\text { Yojana }\end{array}$ & 398 & 1296 & $225.6 \%$ \\
\hline $\begin{array}{l}\text { Number of } \\
\text { beneficiaries of } \\
\text { Bal Sakha } \\
\text { Yojana }\end{array}$ & 380 & 1041 & $173.9 \%$ \\
\hline
\end{tabular}

\section{REFERENCES}

1. Purbey S, Mukherjee K, Bhar C. Reflective practice performance measurement system for healthcare process. Int J Prod Perf Manag. 2007;56(3):241-51.

2. Aitken M, Backliwal A, Chang M, Udeshi A. Understanding healthcare access in India:What is the current state? Parsippany, USA: IMS Institute for Healthcare Informatics; 2013.

3. Chakraborty R, Majumdar A. Relevance of servqual model for determining parameters of quality of 
healthcare service in Indian context. IJRDTM. 2013;20(8):1-17.

4. Kanamori S, Sow S, Castro M, Matsuno R, Tsuru A, Jimba M. Implementation of $5 \mathrm{~S}$ management method for lean healthcare at a health center in Senegal:a qualitative study of staff perception. Glob Health Action. 2015;8.

5. Young F. The Use of $5 \mathrm{~S}$ in Healthcare Services: a Literature Review. IJBSS. 2014;5(10):240-8.

6. Esain A, Williams S, Massey L. Combining planned and emergent change in a healthcare lean transformation. Public Money and Management. 2008;28:21-6.
7. Ikuma LH, Nahmens I. Making safety an integral part of 5S in healthcare. Work. 2014;47(2):243-51.

8. John T, Leonard B. The Promise of lean in health care. Mayo Clin Proc. 2013;88(1):74-82.

9. Bielaszka-DuVernay C. Redesigning acute care processes in wisconsin. Health Aff (Millwood). 2011;30(3):422-25.

Cite this article as: Pandya VP, Patel UV, Kanabar BR, Joshi IV, Kadri AM. Evaluation of implementation of "5S Campaign" in urban health center run by municipal corporation, Gujarat, India. Int J Community Med Public Health 2015;2(3):217-22. 